\title{
Ocena przydatności archiwalnych materiałów kartograficznych dla analiz paleopowierzchni wykonywanych w technikach GIS na obszarze Polski Środkowej
}

\section{Evaluation of usefulness of archival cartographic materials for the GIS analyses of palaeosurfaces in Central Poland}

Zarys treści:

\begin{abstract}
Podczas badań paleogeograficznych często istnieje potrzeba odwołania się do opracowań kartograficznych wydanych w formie drukowanej. Aby je wprowadzić do Systemów Informacji Geograficznej (GIS) należy dokonać ich oceny i weryfikacji, co warunkuje prowadzenie poprawnych analiz oraz stawianie właściwych wniosków. Zagadnienie to jest szczególnie istotne, kiedy istnieje potrzeba scalenia danych z wielu źródeł. W artykule tym przedstawiono ocenę możliwości wykorzystania w systemach GIS dla obszaru Polski Środkowej danych z profili wiertniczych oraz archiwalnych materiałów kartograficznych w postaci map i szkiców geologicznych, publikowanych jako samodzielne opracowania i jako załączniki zamieszczone w monografiach i artykułach naukowych.
\end{abstract}

Słowa kluczowe: mapy i szkice geologiczne, ocena i weryfikacja materiałów źródłowych, badania paleogeograficzne, techniki GIS.

Abstract:

During palaeogeographic research printed cartographic materials are often used. In order to incorporate them into GIS thorough assessment and verification are necessary, since they condition proper analyses of the materials and valid conclusions. Evaluation of the materials is particularly important when information from several data sources is compiled. This paper assesses the possibilities of using a variety of geological materials on Central Poland in GIS, such as data derived from borehole profiles as well as archival geological maps and sketches that were published as stand-alone deliverables or as attachments to scientific monographs and papers.

Key words: geological maps and sketches, evaluation and verification of source materials, palaeogeographical research, GIS techniques.

\section{Wprowadzenie}

W badaniach paleogeograficznych często istnieje potrzeba analizy ukształtowania powierzchni kopalnych w celu ustalenia relacji pomiędzy nimi a rzeźbą współczesną. Jedną z lepszych metod w przypadku małych obszarów badawczych jest pomiar i interpretacja rozmieszczenia niewidocznych warstw geologicznych za pomocą georadaru. Dla większych obszarów badawczych powinno się dokonać interpretacji danych z otworów wiertniczych uwzględniając także informacje pochodzące z szeroko rozumianych pomiarów geofizycznych. Często jednak istnieje sytuacja, kiedy osoba prowadząca badania musi swoje prace oprzeć o już istniejące opracowania kartograficzne. Sytuacja dodatkowo się komplikuje, kiedy analizowany obszar znajduje się w zasięgu opisywanym przez kilka stykających się ze sobą opracowań kartograficznych wydanych w różnym czasie.

W przypadku tradycyjnej analizy kartograficznej ewentualne różnice lub nieścisłości pomiędzy różnymi mapami względnie łatwo jest rozwiązać i wysnuć wnioski. Problemy techniczne mogą się pojawić w momencie kiedy po wprowadzeniu zeskanowanych map do Systemów Informacji Geograficznej (GIS), tworzy się bazy danych lub próbuje się łączyć informacje z kilku ich arkuszy. Największe trudności podczas przetwarzania archiwalnych materiałów źródłowych w systemach GIS sprawiają m.in. niewłaściwe lub niedokładne ich odniesienie przestrzenne, zmieniające się co jakiś czas instrukcje dotyczące kartowania tematycznego, jak i sam rozwój wiedzy na dany temat (np. wydziele- nia stratygraficzne), a także wynikająca z różnych przyczyn niedokładność przy wykreślaniu map i szkiców.

W opracowaniu tym skupiono się na ocenie trzech podstawowych grup materiałów archiwalnych wykorzystywanych do analiz paleogeograficznych. Są to dane z kart otworów wiertniczych, mapy i szkice geologiczne oraz opracowania kartograficzne w monografiach i artykułach naukowych.

\section{Dane z kart otworów wiertniczych}

Dane z otworów wiertniczych dostępne są zarówno w poszczególnych firmach geologicznych, jak i w dużych instytucjach, takich jak np. Narodowe Archiwum Geologiczne. W zależności od instytucji oraz okresu wykonania prac geologicznych, dane te mogą być przechowywane w wersji papierowej (karty otworów wiertniczych) lub w formie elektronicznej bazy danych. Podstawową zaletą oryginalnych kart otworów jest informacja geologiczna uzyskana bezpośrednio w terenie, wadą zaś niekiedy występujące niedokładne lub niewłaściwe podanie lokalizacji lub rzędnej otworu oraz nieczytelność opisu. Elektroniczne bazy danych zawierają już zweryfikowaną - i co najważniejsze - znormalizowaną lokalizację punktów (współrzędne geograficzne, topograficzne oraz rzędna wysokościowa otworu), natomiast pojawiają się błędy powstałe podczas wprowadzania danych z kart otworów. Ponadto duża część tego typu danych często nie zawiera informacji przydatnych do analiz głębiej położonych warstw skalnych. 
Podstawową trudnością przy analizie informacji z karty otworu jest jej weryfikacja. Z różnych doświadczeń badawczych na ten temat wynika, że podczas tej procedury udział zakwestionowanych dokumentacji dochodzi nawet do 50\%, (Roman, Szmidt 2007; Szubert 2009). Najczęściej pojawiającymi się błędami są niewłaściwe oznaczenia granicy czwartorzęd/neogen oraz zbyt miąższe warstwy jednolitych litologicznie osadów czwartorzędu. Zwracał na to uwagę już Galon (1970), a ostatnio Turkowska (2006). Wiele otworów kończy się po osiągnięciu osadów neogeńskich nie przebijając ich, bądź nawiercając je maksymalnie do $1 \mathrm{~m}$. Trudno wówczas jest zinterpretować, czy wydzielenie to stanowi faktyczną powierzchnię podczwartorzędową, czy też jest fragmentem jakichś struktur glacitektonicznych.

W drugim przypadku, geolog opisujący odwiert w załączonej dokumentacji często nie dokonuje precyzyjnego rozdzielenia osadów pod względem litologicznym oznaczając wiele warstw geologicznych, jako np. piasek. Po takim połączeniu w karcie otworu pojawia się informacja o kilkudziesięciometrowej miąższości warstwie piasku tego samego wieku i genezy. Jeśli wiercenie było wykonywane na potrzeby dokumentacji surowcowej nie związanej z osadami czwartorzędu (np. ropa naftowa), wówczas opisaną wyżej sytuację możemy uznać za dopuszczalną. W innych przypadkach opierając się na wiedzy o budowie geologicznej danego obszaru, najczęściej można przypuszczać, że taki układ warstw nie powinien raczej występować. Może to budzić wątpliwości co do jakości opisu całego profilu. Niemniej największą zaletą tego typu danych jest ich duża ilość, możliwość własnej interpretacji zawartych tam informacji, zaś w szczególności oznaczenie granicy pomiędzy neogenem a czwartorzędem.

Osobne zagadnienie stanowi technika wykreślania paleopowierzchni na podstawie danych z profili wiertniczych. W dyskusjach wiele osób zajmujących się tym zagadnieniem uważa, że mapy generowane cyfrowo dają niesatysfakcjonujące wyniki. Uważają oni, że tzw. metody cyfrowe mogą stanowić jedynie element wspomagający wykreślanie map powierzchni kopalnych. W procesie tradycyjnego wykreślania powierzchni kopalnych brak wystarczającej ilości otworów uzupełniany jest wiedzą, doświadczeniem, a przede wszystkim znajomością terenu przez badacza. Na przykład, przy braku odpowiedniej ilości otworów oraz wymaganego umiejscowienia ich w obrębie dna doliny, oprogramowanie komputerowe nie ma podstaw do wyliczenia obniżenia w powierzchni kopalnej, ale i także we współczesnej. Geolog natomiast, znając ogólną budowę geologiczną obszaru, mając nawet nieliczne otwory oraz znając panujący trend w rozwoju rzeźby jest w stanie $z$ dużym prawdopodobieństwem takie obniżenie wyznaczyć. Podobna sytuacja występuje w przypadku osadów zaburzonych. Algorytmy komputerowe mają problem z określeniem, czy dana forma jest kopalnym wzgórzem, czy też może jest to tylko spiętrzenie utworów podłoża. Analizując strukturę osadów w odsłonięciach terenowych, można wywnioskować, że pod zaburzonymi osadami czwartorzędu występuje jakaś wyraźna wyniosłość skał litych. Za przykład można podać odsłonięcie piaskowców przedczwartorzędowych w klifie zbiornika Jeziorsko. Pierwotnie na podstawie widocznych w odsłonięciu struktur zakładano istnienie położonego głębiej progu skalnego. Odsłonięcie skał przedczwartorzędowych przez procesy brzegowe w zbiorniku może to przypuszczenie potwierdzać (Załoba, Kamiński 1999; Szmidt 2006).

Przykładem obrazującym kwestie różnic w interpretacji danych z kart otworów mogą być dwa szkice odkryte dołączone do objaśnień do Szczegółowej mapy geologicznej Polski w skali 1: 50000 - arkusz Inowłódz (Kłoda 1993) oraz arkusz Sulejów (Brzeziński 1992). Autor dokonał przetestowania obrazu powierzchni w dwóch wariantach (rys. 1 i 2):

a) ukształtowanie powierzchni kopalnej wykreślonej przez autora arkusza SMGP,

b) ukształtowanie powierzchni kopalnej wygenerowanej na podstawie rzędnej spągu osadów czwartorzędu.

Przykłady szkiców odkrytych dla arkusza SMGP Sulejów uwidaczniają, że mapy powierzchni kopalnych wykreślone przez człowieka mogą być udoskonalone poprzez wzbogacenie ich powierzchni o inne informacje o budowie geologicznej obszaru badań i terenów przyległych. Na rys. 1 wyraźnie widoczne jest obniżenie we wschodniej części oraz kilka małych form dolinnych rozcinających wyniesienie w południowo-wschodniej części obszaru szkicu.

Rys. 2, wygenerowany automatycznie metodą krigingu w oprogramowaniu GIS, przedstawia podobną konfigurację powierzchni, jednakże z mniejszą ilością szczegółów. Takie zestawienie może świadczyć o zachowaniu proporcji pomiędzy ilością dostępnych otworów wiertniczych a interpretacją powierzchni. Autor arkusza SMGP uszczegółowił obraz względem informacji pochodzącej tylko z kart otworów wiertniczych, natomiast nie zmienił go istotnie. Osobne pytanie stanowi, czy szkic został uszczegółowiony wystarczająco.

Za przykład możliwej nadinterpretacji można uznać natomiast obraz powierzchni podczwartorzędowej dla arkusza SMGP Rzeczyca (Kłoda 1993). W swojej interpretacji mapy (rys. 3), autor mapy prawdopodobnie zakłada zgodność przebiegu poszczególnych dolin z orientacją nieciągłych struktur tektonicznych. Jeśli jednak obraz ten zestawimy z mapą powstałą tylko w oparciu o dane z kart otworów wiertniczych (rys. 4), można dojść do wniosku, że autor mógł nie zachować właściwych proporcji pomiędzy ilością danych jaką posiadał a interpretacją powierzchni kopalnej. Istnieją zbyt duże różnice co do szczegółowości oraz położenia innych elementów reliefu. Rodzi się wówczas pytanie, w jakim stopniu można dane z kart otworów wiertniczych uzupełnić o dodatkowe elementy wyinterpretowane w oparciu o wyniki innych badań geologicznych. Stąd zdaniem autora, informacje z otworów wiertniczych mogą stanowić cenne źródło danych, lecz w połączeniu z informacjami pochodzącymi z profili i przekrojów geologicznych oraz wiedzą pochodzącą z badań terenowych na analizowanym obszarze.

Uwzględniając to, że otworów wiertniczych ciągle przybywa, można co jakiś czas uzyskiwać coraz doskonalsze obrazy paleopowierzchni. Jeśli weźmiemy jednak pod uwagę konieczność weryfikacji danych z tysięcy profili wiertniczych, metoda opisana wyżej jest możliwa do realizacji głównie dla małych obszarów badawczych. Dla większych obszarów badawczych ich weryfikacja w zasadzie staje się trudna do zrealizowania, a szczegółowa znajomość wszystkich istotnych stanowisk terenowych, które mogą wnieść ważne informacje paleogeograficzne jest $w$ zasadzie nie osiągalna dla jednej osoby. 


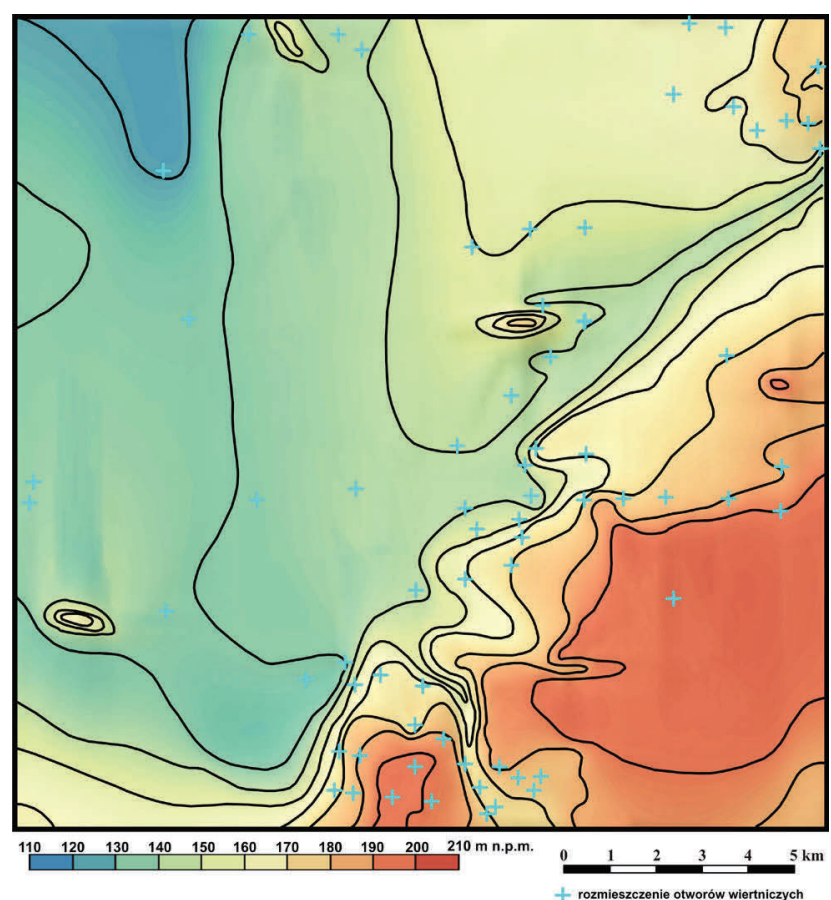

Rys. 1. Ukształtowanie powierzchni podczwartorzędowej w obrębie obszaru objętego arkuszem SMGP Sulejów.

Rysunek przetworzony i uplastyczniony metodą warstwobarwną z cieniowaniem na podstawie szkicu odkrytego załączonego do objaśnień do SMGP Arkusz Sulejów (Brzeziński 1992)

Fig. 1. The shaping of the Quaternary bedrock within the area covered by Detailed Geological Map of Poland, sheet Sulejów.

Figure processed and plasticized colorful and shaded method based on the Explanations to the Detailed Geological Map of Poland in scale 1:50 000, sheet Sulejów (Brzeziński 1992)

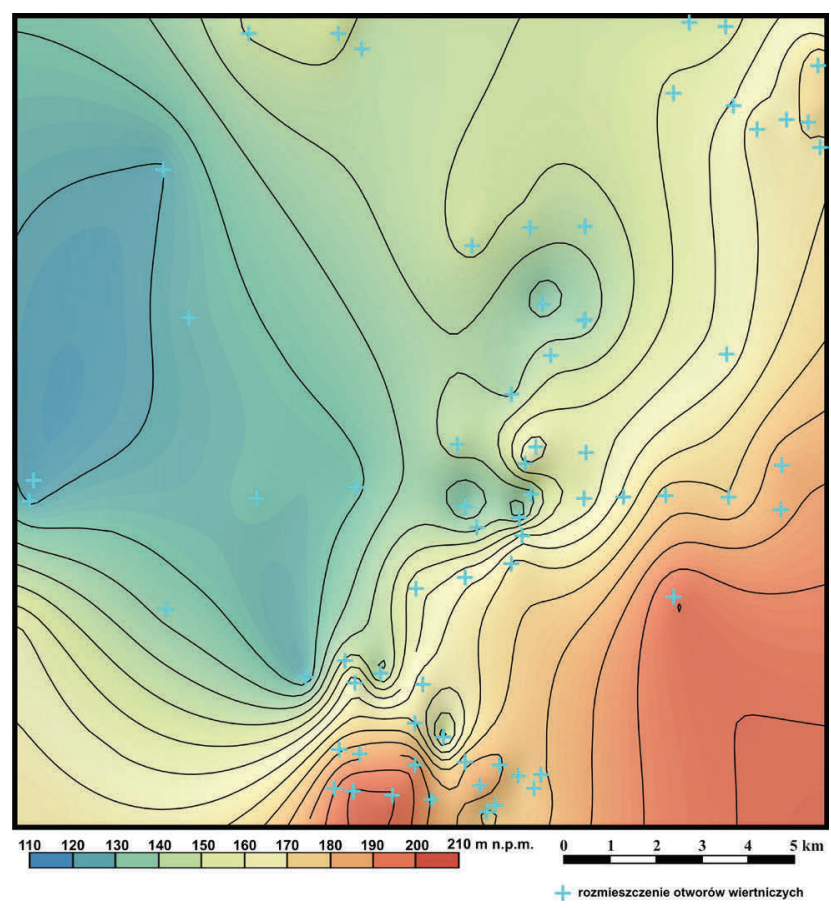

Rys. 2. Ukształtowanie powierzchni podczwartorzędowej w obrębie obszaru objętego arkuszem SMGP Sulejów na podstawie danych z profili wiertniczych załączonych do dokumentacji SMGP Ark. Sulejów (Brzeziński 1992)

Fig. 2. The shaping of the Quaternary bedrock within the area covered by Detailed Geological Map of Poland, sheet Sulejów (Brzeziński 1992), based on the borehole data

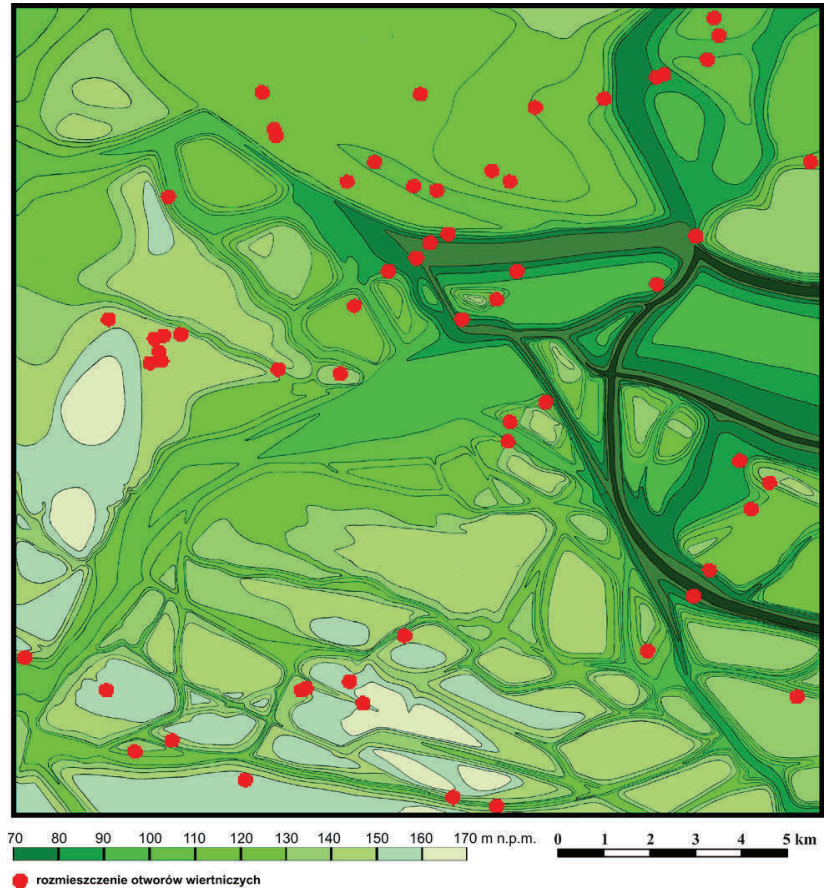

Rys. 3. Ukształtowanie powierzchni podczwartorzędowej w obrębie arkusza SMGP Rzeczyca.

Rysunek przetworzony i uplastyczniony metodą warstwobarwną z cieniowaniem na podstawie szkicu odkrytego załączonego do objaśnień do SMGP Ark. Rzeczyca (Kłoda 1993)

Fig. 3. The shaping of the Quaternary bedrock within the area covered by Detailed Geological Map of Poland, sheet Rzeczyca.

Figure processed and plasticized colorful and shaded method based on the Explanations to the Detailed Geological Map of Poland in scale 1:50 000, sheet Rzeczyca (Kłoda 1993)

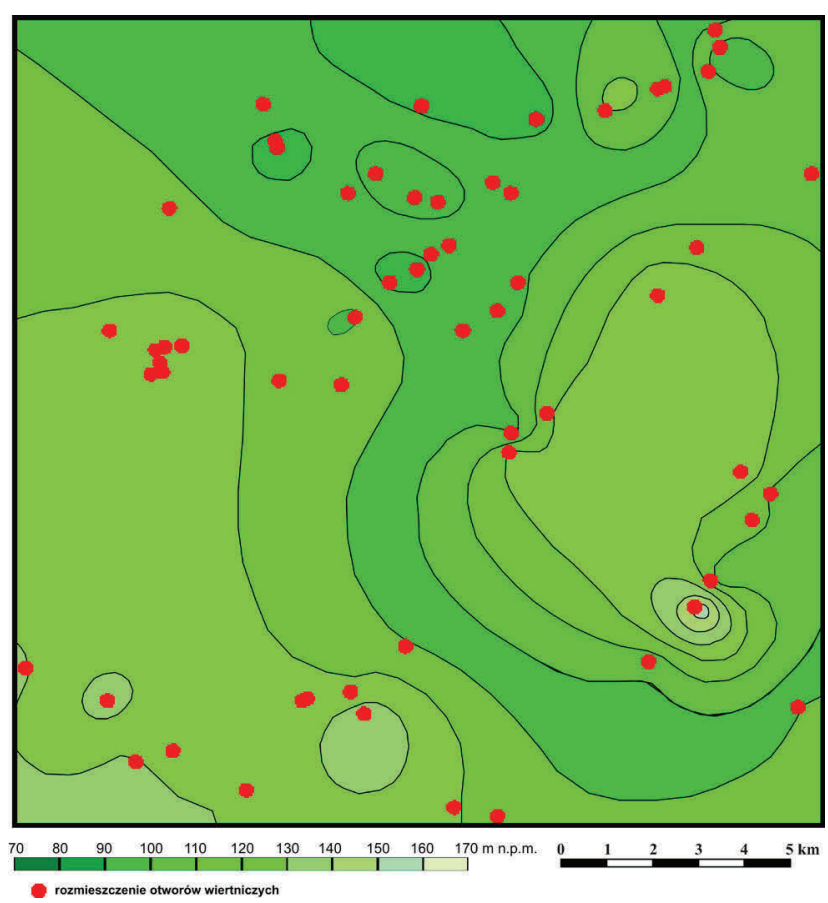

Rys. 4. Ukształtowanie powierzchni podczwartorzędowej w obrębie Arkusza SMGP Rzeczyca na podstawie danych z profili wiertniczych załączonych do dokumentacji SMGP Ark. Rzeczyca (Kłoda 1993)

Fig. 4. The shaping of the Quaternary bedrock within the area covered by Detailed Geological Map of Poland, sheet Rzeczyca, based on the borehole data 
Informacje z otworów wiertniczych, oprócz baz danych, z reguły są dołączone do Szczegółowych map geologicznych Polski w skali 1:50 000 oraz Geologicznych map Polski bez utworów czwartorzędowych w skali 1:200 000. W zależności od arkusza, lokalizacja otworów oraz ich opis może się znajdować na mapie lub w objaśnieniach do mapy, ponadto dane otworów wiertniczych powinny być załączone do dokumentacji mapy geologicznej. Do podstawowych wad tego źródła danych należą ograniczona ilość otworów udokumentowana do okresu tworzenia danej mapy oraz nie zawsze prawidłowo oznaczona lokalizacja otworu w dokumentacji (Marciniak 2004). Niewątpliwą natomiast zaletą jest to, że tak załączone informacje o otworach są już zweryfikowane przez autora danej mapy.

\section{Mapy i szkice geologiczne}

Do analiz powierzchni kopalnych dobrym rozwiązaniem mogą się okazać gotowe opracowania kartograficzne takie, jak mapy i szkice geologiczne.

Podstawowym źródłem danych o ukształtowaniu powierzchni podczwartorzędowej są szkice odkryte w skali 1:100 000 dołączone do objaśnień do Szczegółowej mapy geologicznej Polski (SMGP) w skali 1:50 000. Jest to zasób bardzo zróżnicowany jakościowo. Zasadniczo w procesie tworzenia SMGP powinien zostać wykonany szkic ukształtowania podłoża czwartorzędu. Jednak przez dziesięciolecia modyfikacji ulegała instrukcja do kartowania Szczegółowej mapy geologicznej Polski, z czego obecnie wynika problem przy scalaniu danych z wielu arkuszy.

W najstarszych mapach, obejmujących Polskę Środkową, szkice takie nie były załączane, później zaś wykonywane były w dwóch wersjach. Pierwsza, najczęściej spotykana, to szkic ukształtowania powierzchni starszej od czwartorzędu. Druga wersja to mapa ukształtowania powierzchni starszej niż kenozoiczna. Jeśli autor dołączył oba szkice jednocześnie, wówczas opracowanie takie zyskuje na wartości. Jednak, jeśli zamieścił tylko mapę powierzchni starszej od kenozoicznej, wówczas taki szkic nie nadaje się do interpretacji podłoża podczwartorzędowego i zarazem jest on niezgodny tematycznie z większością szkiców załączonych do innych SMGP. Jest to istotna kwestia przy analizie wpływu podłoża starszego na osady i rzeźbę współczesną, ponieważ niezwykle ważną rzeczą staje się rozstrzygnięcie, czy procesy glacjalne zachodziły na nieskonsolidowanych osadach neogenu i paleogenu (iły, mułki, piaski itp.), w zasadzie niewiele się różniących od czwartorzędowych, czy na litych skałach mezozoicznych lub paleozoicznych (wapienie, margle, piaskowce itp.). Dlatego cennym uzupełnieniem SMGP jest szkic przedstawiający litologię powierzchni starszej od czwartorzędu. Niestety, szkic litologii powierzchni podczwartorzędowej nie zawsze jest załączany do mapy lub jeśli jest załączany, to nie jest publikowany szkic jej ukształtowania. Zdarzają się też przypadki, że w chwili wydania danej mapy geologicznej, objaśnienia do niej nie zostały opublikowane. W powyższych sytuacjach obraz uzyskany na podstawie tylko tego źródła może być niekompletny.

Innym problemem przy pozyskiwaniu obrazu powierzchni podczwartorzędowej z SMGP jest proces scalania danych poszczególnych arkuszy. Jedną z zasad tworzenia map tego typu jest nawiązywanie do arkuszy sąsiednich. Praktyka wskazuje, że zasada ta nie zawsze była respektowana. Nieprzestrzeganie tego wymogu może wynikać głównie z faktu wspomnianych wcześniej zmian w kryteriach wydzielania oraz ogólnego rozwoju wiedzy paleogeograficznej i geologicznej. Wada ta uwidacznia się szczególnie mocno na mapach powierzchniowych, aczkolwiek objawia się także w przypadku szkiców odkrytych. Problem ten wyraźnie jest widoczny także na prowadzonym przez PIG-PIB Geoportalu „Ikar”, gdzie cyfrowy obraz SMGP jest mocno uproszony i zawiera ponadto liczne luki, które będą mogły być uzupełnione dopiero po reinterpretacji istniejących map. Zdaniem autora oraz wielu geologów i geomorfologów, ze względu na rozwój badań wiele starszych arkuszy SMGP powinno być wykonane ponownie.

W przypadku szkiców odkrytych występują dwie podstawowe nieścisłości. Pierwsza polega na nieprecyzyjnym dociągnięciu poziomic względem poziomic arkusza sąsiedniego. Druga nieścisłość to znacząca lub całkowita niezgodność poziomic względem obszaru sąsiedniego. Dla tej drugiej opcji sytuacja może się komplikować, jeśli kolejne arkusze SMGP próbują nawiązywać do wcześniej niepasującego arkusza. Błędy pierwszego typu są proste do usunięcia, a korekty można dokonać podczas digitalizacji mapy poprzez właściwe dociągnięcie lekko odchylonej warstwicy do odpowiadającej jej warstwicy na arkuszu sąsiednim. W przypadku błędów polegających na całkowitym niedopasowaniu szkicu do szkiców sąsiednich, problem można rozwiązać poprzez ponowną reinterpretację danych z otworów wiertniczych załączonych do mapy lub profili geologicznych udostępnianych w różnych geobazach. Ponadto można dokonać próby przeniesienia rysunku rzeźby kopalnej z Map geologicznych Polski bez utworów czwartorzędowych w skali 1:200 000, o ile ta względnie pokrywa się z rysunkiem paleopowierzchni na SMGP. Prób wykreślenia map ukształtowania powierzchni podczwartorzędowej dla obszaru Polski Środkowej na podstawie szkiców odkrytych załączonych do objaśnień do SMGP było wiele, m.in. Klatkowa (1972), Marciniak (2004), Forysiak (2004, 2005), Turkowska (2006). Ze względu jednak na zróżnicowaną jakość poszczególnych map, nigdy nie udało się skompilować tego typu opracowania dla większego obszaru badawczego.

Kolejnym ważnym źródłem danych kartograficznych są wymienione wcześniej Geologiczne mapy Polski bez utworów czwartorzędowych w skali 1:200 000, wchodzące w skład Mapy geologicznej Polski 1:200 000 (Mojski 1989). Przedstawiają one m.in. litologię powierzchni podczwartorzędowej na tle jej ukształtowania. Ze względu na skalę, teoretycznie powinny być mniej szczegółowe, niż szkice geologiczne odkryte w skali 1:100 000 załączone do SMGP. Ich cięcie warstwicowe wynosi od 10 do 20 metrów. Uzależnione jest to głównie od deniwelacji powierzchni kopalnej. Na obszarach, gdzie deniwelacje są niewielkie stosuje się cięcie 10-metrowe, zaś dla obszarów wyżynnych cięcie 20-metrowe.

Cenną informacją na tych mapach jest ich główna treść, czyli litologia powierzchni podczwartorzędowej. Łatwiej jest wówczas wnioskować, czy np. istniejące większe skomplikowanie rzeźby może wynikać z procesów działających jeszcze przed czwartorzędem, czy też już w czwartorzędzie, czy mogły powstać w wyniku procesów erozji i denudacji, czy też procesów glacitektonicznych. Oczywiście można tylko na ich podstawie wygenerować obszar powierzchni podłoża czwartorzędu, jednak co oczywiste będzie on mniej dokładny niż ten uzyskany ze szkiców odkrytych dołączonych do SMGP. Co jednak istotne, obraz na mapach 
przeglądowych został uzyskany także częściowo w oparciu o szkice odkryte dołączone do wydanych ówcześnie objaśnień do SMGP.

Podstawową wadą tych map jest czas, który upłynął od ich wydania. Powstawały one w latach 1969-1998 z tym, że dla obszaru Polski Środkowej wydane zostały głównie w latach 70. XX wieku. Za zaletę natomiast można uznać usystematyzowanie zaprezentowanych informacji. Interpretacja danych źródłowych do tych map, podobnie jak w przypadku SMGP, dokonywana była przez jednego autora lub konkretny zespół osób, jednakże mniejsza liczba arkuszy ułatwiała wzajemne nawiązywanie przez twórców do treści map sąsiadujących. W odróżnieniu od SMGP na opisywanym obszarze badań, treść poświęcona litologii oraz ukształtowaniu powierzchni podczwartorzędowej nawiązuje do siebie pomiędzy poszczególnymi arkuszami map.

\section{Opracowania kartograficzne w monografiach i artykułach naukowych}

Trzecie źródło danych kartograficznych dotyczących podłoża czwartorzędu, to opracowania zamieszczone w monografiach i artykułach naukowych. Niewątpliwą ich zaletą jest to, że mapy takie nie były tworzone z obowiązku umieszczenia takiej treści w dokumentacji kartowania, lecz stanowiły główny bądź ważny wątek badawczy. Do ich wykreślenia autorzy używali wszelkich dostępnych ówcześnie źródeł danych, zaś przy interpretacji ważnym czynnikiem było wspomniane wcześniej doświadczenie oraz znajomość terenu badań. Zdaniem autora, mapy te charakteryzują się największą dokładnością oraz wiarygodnością przedstawianej treści.

Ich mankamentem jest natomiast technika wykonania, szczególnie zaś szkiców wykreślonych dawniej. Mapy znormalizowane takie, jak Szczegółowa mapa geologiczna Polski, chociaż dawniej wykonywane techniką tradycyjną, musiały ściśle nawiązywać do osnowy geodezyjnej. Arkusze były wykonywane na podkładzie topograficznym w układzie współrzędnych 1942. Wprawdzie dawniej trudno było je scalać w prosty sposób, to jednak pojedyncze arkusze w zdecydowanej większości posiadają poprawną orientację przestrzenną, co jest niezwykle ważne podczas procesu przetwarzania danych w systemach GIS.

Powyższe warunki często nie są spełniane przez szkice i mapy tworzone na potrzeby publikacji książkowych. Do najczęściej spotykanych nieścisłości należą nieokreślenie precyzyjnego położenia oraz wymuszone scalanie materiałów zapisanych w tych samych bądź różnych układach współrzędnych.

W pierwszym przypadku autorzy nie orientują szkicu w siatce geograficznej bądź topograficznej nie nanosząc przy tym innych wyraźnych punktów orientacyjnych. Szkicu takiego, pomimo dużej dokładności, nie da się poprawnie osadzić w programie kartograficznym, a ponadto trudno jest go skonfrontować z mapą topograficzną czy zdjęciem lotniczym.

W drugim przypadku, dane z map ze względu na możliwości techniczne, łączone były ręcznie, często niezgodnie z zasadami przekształceń kartograficznych. Przykładowo przy odwzorowaniu Gaussa-Krügera dla map wielkoskalowych obraz arkusza stanowi w przybliżeniu trapez. Arkuszy o takim kształcie nie da się bez przekształceń matematycznych złączyć. Próby osadzenia w oprogramowaniu niektórych map scalonych ręcznie za pomocą narzędzia „Georeferencer" (poprzez wskazanie współrzędnych punktów charakterystycznych) wskazuje, że treść kartograficzna z różnych map została połączona metodą niekartograficzną, czyli poprzez dociągnięcie do siebie na kalkach lub w programie graficznym, niestykających się elementów mapy. Metodą tą wprawdzie uzyskiwano efekt wizualny, jednakże szkice wykonane $w$ ten sposób trudno wiązać z danymi kartograficznymi przetwarzanymi współcześnie. Wada ta szczególnie ujawnia się w momencie, kiedy warstwę taką próbuje się nałożyć na prawidłowo utworzony i zlokalizowany Cyfrowy Model Wysokościowy (CMW). Wówczas np. przebieg współczesnej rzeki stanowiącej tło mapy, nie zawsze zgadza się z sytuacją morfometryczną przedstawianą przez CMW.

\section{Podsumowanie}

Wszystkie wymienione wyżej źródła danych kartograficznych opisujące powierzchnię podczwartorzędową mają różną dokładność pionową oraz poziomą, oraz w różnym stopniu dane źródłowe zostały zweryfikowane i zinterpretowane przez autorów. Dlatego też nie dają się one połączyć ze sobą bezpośrednio. Za najbardziej spójne, ale i najmniej szczegółowe można uznać Mapy geologiczne Polski bez utworów czwartorzędowych w skali 1:200 000. Za najbardziej wiarygodne, lecz mogące także posiadać największy błąd związany z przekształceniami kartograficznymi można uznać mapy zamieszczone $w$ monografiach i artykułach naukowych. Szczegółowe mapy geologiczne Polski w skali 1:50 000 wraz ze szkicami odkrytymi w skali 1:100 000 stanowią źródło mocno zróżnicowane jakościowo oraz niekompletne (nie do każdego arkusza dołączony jest szkic ukształtowania podłoża czwartorzędu). Po ich weryfikacji, dla mniejszych obszarów badawczych mogą one stanowić cenny zestaw danych wejściowych do analiz wykonywanych w technikach GIS.

Przy tworzeniu szkiców ukształtowania podłoża czwartorzędu dla obszarów badawczych położonych w Polsce Środkowej występuje więc problem związany z jakością materiałów źródłowych oraz możliwościami technicznymi ich przetwarzania. Obraz dla dużych obszarów badawczych utworzony na podstawie zinterpretowanych danych z otworów wiertniczych jest ze względu na ich ilość w zasadzie niemożliwy do zrealizowania, zaś automatyczne generowanie siatek powierzchni kopalnych daje mało wiarygodny obraz. Mapa uzyskana poprzez digitalizację i łączenie różnych pod względem szczegółowości arkuszy również może dać niesatysfakcjonujący efekt.

Obraz uzyskany tylko na podstawie Geologicznych map Polski (wyd. B) w skali 1:200 000 może stanowić wprawdzie duże uproszczenie, jednakże jest najbardziej spójny pod względem rzeźby, litologii i okresu opracowania.

Autor wychodzi z założenia, że każdy twórca realizujący projekt Mapy geologicznej Polski bez utworów czwartorzędowych w skali 1:200 000 posiadał największą ówcześnie wiedzę na temat konkretnego obszaru, a ponadto zgodnie z prawem, wykonanie takiego projektu, podobnie jak SMGP, wymagało recenzji oraz zatwierdzenia przez odpowiednie ograny Państwowego Instytutu Geologicznego, co także podnosi wiarygodność tych źródeł. Mapy te powinny stanowić wiarygodną podstawę do analiz paleogeograficznych w przypadku dużych obszarów badawczych. 


\section{Literatura}

Brzeziński, H., 1992. Objaśnienia do Szczegółowej mapy geologiczne Polski w skali 1:50 000, ark. Sulejów. Państwowy Instytut Geologiczny, Warszawa, 1-58.

Forysiak, J., 2004. Wpływ podłoża mezozoicznego na morfologię i przebieg doliny Warty między Burzeninem i Dobrowem, [w:] III Świętokrzyskie spotkania geologiczno-geomorfologiczne nt. Rzeźba i osady czwartorzedowe na tle struktur starszego podłoża obszaru Polski, „Jodłowy Dwór” pod Świętym Krzyżem, 13-15.05.2004, Kielce, 22-23. Forysiak, J., 2005. Rozwój doliny Warty między Burzeninem i Dobrowem po zlodowaceniu warty. Acta Geographica Lodziensia 90, 1-116.

Galon, R., 1970. Uwagi o wpływie konfiguracji i struktury podłoża plejstocenu na rozwój sieci dolinnej Polskiego Niżu. Acta Geographica Lodziensia 24, 155-165.

Klatkowa, H., 1972. Paleogeografia Wyżyny Łódzkiej i obszarów sąsiednich podczas zlodowacenia warciańskiego. Acta Geographica Lodziensia 28, 1-220.

Kłoda, P., 1993. Objaśnienia do Szczegółowej mapy geologicznej Polski w skali 1:50 000, ark. Rzeczyca. Państwowy Instytut Geologiczny, Warszawa, 1-50.

Marciniak, M., 2004. Rzeźba podczwartorzędowych powierzchni strukturalnych na obszarze Łodzi. Przegląd Geologiczny 52(10), 1007-1007.
Mojski, J., 1989. Mapa geologiczna Polski w skali 1:200 000. Kwartalnik Geologiczny 33(1), 73-80.

Roman, M., Szmidt, A., 2007. Litologia podłoża osadów zlodowacenia wisły w obszarze południowo-wschodniej części Pojezierza Kujawskiego i Kotlinie Płockiej. Materiały Konferencyjne XIV Konferencji Stratygrafia Plejstocenu Polski nt. „Plejstocen Kujaw i dynamika lobu wisły w czasie ostatniego zlodowacenia”, Ciechocinek, 3-7 września 2007”. Państwowy Instytut Geologiczny, 125-127.

Szmidt, A., 2006. Wpływ wychodni oraz podłoża mezozoicznego na rzeźbę i osady plejstocenu okolic Siedlątkowa. Materiały Konferencyjne XIII Konferencji Stratygrafia Plejstocenu Polski nt. Plejstocen południowej Warmii i zachodnich Mazur na tle struktur podłoża", Państwowy Instytut Geologiczny, 136-138.

Szubert, M., 2009. Problem of the paleo-Warta river valley on the Woźniki-Wielun Upland in the light of geostatistical spatial analysis of the sub-Pleistocene surface hypsometry. Geoinformatica Polonica 9, 93-115.

Turkowska, K., 2006. Geomorfologia regionu łódzkiego, Wydawnictwo Uniwersytetu Łódzkiego, Łódź, 1-238.

Załoba, M., Kamiński, J., 1999. Przykłady struktur glacitektonicznych odsłaniających się w klifie zbiornika Jeziorsko, [w:] Nauki geograficzne a edukacja społeczeństwa, t. 2, Region łódzki. Materiały XLVIII Zjazdu Polskiego Towarzystwa Geograficznego, Wydawnictwo GROTESK, Łódź, 227-230. 